その家族・そのまた草鞋を作る人という風に極めて多くの 人たちを受けている公器としての会社だと認識している.

\section{2. 仕事の本質をどう捉えるのか}

\section{1 ふっ素樹脂の加工は手段, 顧客や社会の課題を解 決するのが目的, 報酬は結果}

従って, 顧客課題を解決するためであれば，ふっ素樹脂 の加工に自らの仕事のドメインを限ることでなく，そこで 培った技術的な強みを他の手段に展開するのは当然と考え る. シリコーンコーティングもその発想で展開している.

\section{2 報酬によって得られるもの}

人生という単位で見れば，打金もその幸福を達成する手 段の一つに過ぎない，衣食住（最低限の）を得たら，それ から先の金銭の目的は人に敬意を持たれる，趣味で自己満 足を得る等ということになるのだろうが，段々とその限界 効用は派減して行く，それらは言わば技金を通じなくても 得られるものでもある．正岡子規は「人は出来るだけ少な い報酬で人よりも多くの仕事をするのがえらいぞなもし」 と言い切ったがそれは極端な表現だとしても，少なくとも この国では人より働きが悪くて多くの収入を得るのは「恥 ずかしい」という文化があるはず。これは忘れられてはい けないと思う，金銭は重要な尺度だが，成果主義などで金 銭に尺度を統一しょうとした失敗は貴重な経験としておき たい.

\section{3 誇りとモチベーション}

話は戻るが，金銭以外でも家族からの敬意や友人からの 賞賛, あるいは自己満足を達成することは大いに可能であ るし，虚しさもつきまとわない，家族のカミングデーを作 り，ユニフォームも見栄えが良いものに変えた。達成感を 味わい会社として感謝を表する手段を尽くす，これにも尽 カしているつもりである.「楽しくなければ仕事じゃない」 というのはこういう意味を込めている.

\section{3 . 松浦・北部九州の文化}

\section{1 外部に対しては比較的オープン}

「よそ者」という言葉は滅多に使われない。これは外部 から入ってきた人間には結構オープンだということ。この 風土は長崎の歴史と関係があるのか，一度深く掘り下げた い.

\section{2 融和とホンネ}

よそ者を容易に受け入れ，文化融合もするが，但しそれ ら「異文化」とも表立って議論するのは苦手な様に感じる. 従ってホンネを語るには酒の力も必要となる。これが社内 の酒の消費量を増している要因かも知れないが，このこと は決して軽視せずに大切にしたい。「酒の力を借りないと 何も言えないのか?」ではなく「酒のおかげで大いに本音 の議論が出来る」とポジティブに捉えている.

\title{
第二部「ふっ素樹脂の加工技術と用途展開」
}

\section{1.はじめに}

1938 年に米国デュポン社の Roy. J. Plunkettによって発 見されたPTFE（四ふっ化エチレン樹脂）は，ふっ素樹脂 の中でもテフロンとして有名である. 1946 年には量産が 開始され，日本では 1957 年から輸入販売が開始された。

当社は, 日本で最初にふっ素樹脂の加工を始めた．1963 年に中興ファイバーズ侏を設立し，米国ダッジファイバー ズ社と技術提携した後，社名を日本ダッジファイバーズ侏 に変更した. 1964 年には, 長崎県松浦市に工場が竣工し, ふっ素樹脂製品の製造販売を開始した. 1977 年には，米 国ダッジファイバーズとの技術提携が終了した。 その後， 新たに社名を中興化成工業侏と変更する.

ここでは，当社が得意とする PTFE 含浸繊維織布に特 化した加工技術の解説を行い，用途に扔いては，国内では 1 社だけとなった建築用膜材料に関して触れる.

\section{2 . ふっ素樹脂の種類}

PTFE は，炭素（C）とふっ素（F）のみからなる化合 物で, 分子が剛直で, 分子間凝集力が小さいため, 通常は 極めて高い分子量となっている．そのためPTFE は高粘 度を示し, 融点以上での流動性がないため, 一般的な成形 加工法は使えない。この加工性を解決するために, ふっ素 の一部を塩素原子や水素で置換した共重合による改質が進 み, 射出成形や押し出しの溶融成形が出来るふっ素樹脂が
開発された.

現在，ふっ素樹脂の仲間として取り扱っている樹脂は以 下の 9 種類となっている.

(1) ポリテトラフロロエチレン (PTFE)

(2) パーフルオロアルコキシアルカン (PFA)

（3）パーフルオロエチレンプロペンコポリマー（FEP）

(4) エチレンーテトラフルオロエチレンコポリマー (ETFE)

(5) ポリふっ化ビニリデン (PVDF)

（6）ポリクロロトリフルオロエチレン（PCTFE）

（7）エチレンークロロトリフルオロエチレンコポリマー (ECTFE)

（8）テトラフルオロエチレンーパーフルオロジオキソール コポリマー (TFE/PDD)

（9）ポリふっ化ビニル（PVF）

\section{3. ふっ素樹脂の特性}

(1) 耐熱, 耐寒性

ふっ素樹脂の種類によって異なるが融点は $200^{\circ} \mathrm{C}$ 以上で, 使用可能温度は $-250^{\circ} \mathrm{C} \sim 260^{\circ} \mathrm{C}$ と広範囲にわたる.

（2）耐薬品性

高温, 強酸, 強アルカリに不活性で溶剂に不溶.

（3）難燃性

UL 94 試験で V-0 の性能が有り，限界酸素指数も $95 \%$ 以上のものが多い.

（4）耐候性 
紫外線による劣化が殆どなく，長期間屋外で使用しても 不変である。

（5）電気特性

高い絶縁特性と高周波での低損失特性を持つ.

(6) 摩擦特性

他の樹脂に類を見ないすべり特性を持つ.

（7）非粘着特性

接着剂を受け付けない。

\section{PTFE 含浸繊維織布の加工方法}

PTFE は，溶融粘度が $10^{10 \sim 12} \mathrm{~Pa} \cdot \mathrm{s}$ 程度あり，ゴム状弾 性体にとどまり流動性を示さない. そのため汎用プラス チックのような成形手段は適用できず，特にコーティング と言われる織物やフィルム等に使われる装置も使用できな い.

PTFE 含浸は，乳化重合された水系分散液を界面活性剂 で安定化させたディスパージョンを使用する。この分散液 をガラス繊維織布やアラミド繊維織布などの耐熱緎維織物 に含浸し, 乾燥後焼成を行い, 焼成塗膜を形成する加工方 法である。

図 1 に PTFE 含浸ガラス繊維織布の製造方法を示す. ガイドロール付含浸タンクと縦型の炉を用い, 乾燥後熱処 理を行い, PTFEを焼結させる.

ディスパージョンには界面活性剤が安定剤として使用され ており，含浸後の乾燥工程では，急加熱による樹脂発泡な どの現象が生じる.このためライン速度は, 非常に遅くな る.また，含浸後乾燥された PTFE 樹脂膜は，焼成時の 加熱及び冷却において樹脂の膨張収縮が起こり，マッドク ラックが発生しやすくなる。一度に厚い塗膜を得ることが 出来ないため, 繰り返し塗工を行うことで, 所定の厚さに 仕上げていく.

数回の含浸焼成を繰り返した繊維織布の表面状態を図 2 に示す．同様に断面状態を図 3 に示す。

\section{5．PTFE 含浸繊維織布の二次製品及び用途}

PTFE 含浸繊維織布は, ガラス䋊維織布やアラミド繊維織

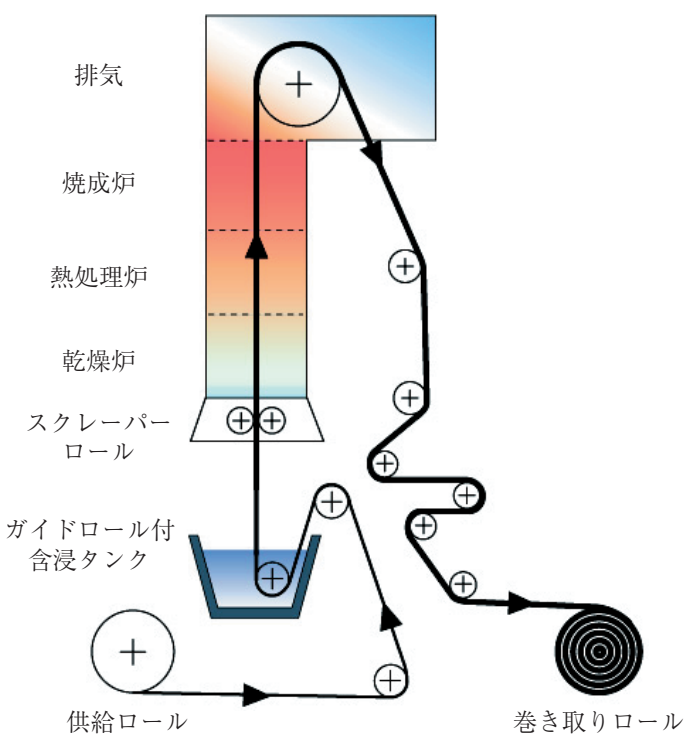

図 1 製造装置
布を基材として，その両面に PTFEが被覆されている. そのため表面は，ふっ素樹脂の特性をそのまま備えており， 基材による寸法安定性に優れた複合材料となる.

厚さにつれて強度, 剛性も高くなり, 織布の厚み, 被覆樹 脂量を変化させる事で以下のように多岐にわたる分野で使 用されている。

（1）リリースシート・離型用シート

相手材との離型用途として使用される．例としてはクッ キー製造時にオーブンの敷物として，また，工業用として は粘着物の調合などを扱う際やすべり特性, 非粘着特性を 利用した用途に使用されている.

(2) 建築用材料

建築用途としては，東京ドームをはじめとする恒久建築 用膜材料として使用されており，日本国内では 20 年以上 の実績を持っている。

また，PTFE 含浸纎維織布を多層積層材とした製品は， 免震構造用や橋梁，プラントのすべり支承としても使用さ れている.

(3) コンベアベルト

PTFE 含浸繊維織布をコンベアベルトとしてエンドレス 加工したものは, 連続熱処理, 離型などの軽搬送用ベルト のほか包装用としてヒートシール部分の離型ベルトやシュ リンク包装等の加熱処理搬送用ベルトとして使用される.

また，食品用途としては連続製造するときの加熱，冷凍，

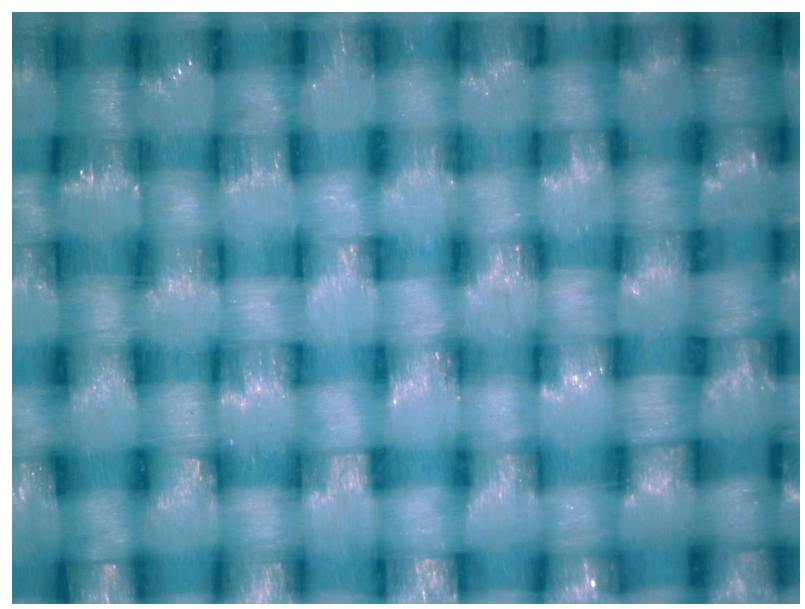

図 2 PTFE 含浸ガラス繊維織布表面

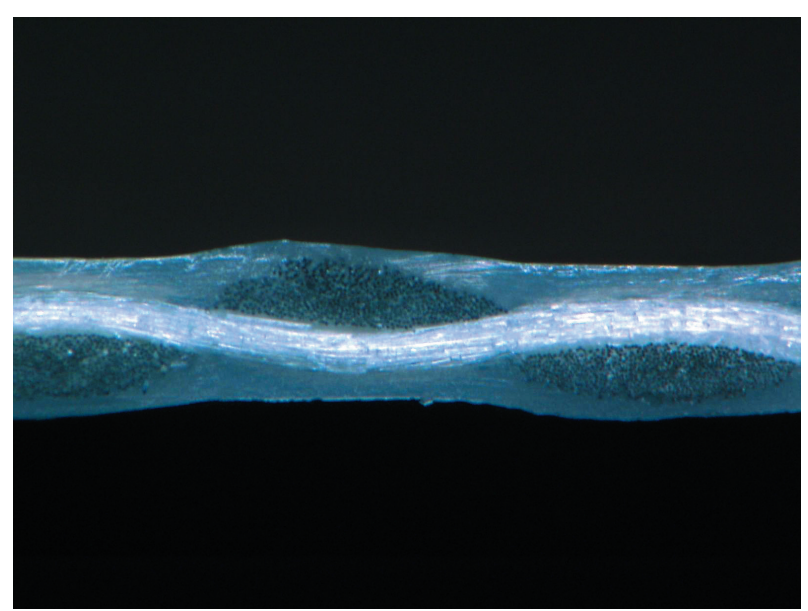

図 3 PTFE 含浸ガラス繊維織布断面 
成形用や蒸し工程での搬送用ベルトとして使用されている.

ウレタン，ポリエチレンなど汎用樹脂のコンパウンドや 成形を連続で行う際の搬送用ベルトとしても使用される.

その他, 繊維製品の加熱乾燥工程や液晶, 半導体, ゴム 製品などの製造時の加熱処理, 洗浄工程などでも各種使用 されている。

(4) 粘着テープ

PTFE 含浸繊維織布の片面に特殊表面処理を行ない, 耐 熱粘着剂を塗布した粘着テープで, 加熱, 圧着, 離型用途 をはじめ食品, 日用品等の包装時のヒートシール機にヒー ターと包装材との離型用途として使用されている.

また, 沉用プラスチックの加熱処理炉の不純物付着防止 として炉内壁面やキャリアロールへのライニングなどにも 使用されている.

（5）銅張り積層板

PTFE 含浸繊維織布と銅箔を加熱圧着積層した製品は, プリント配線基板として使用されている.

主用途としては, 衛星通信, 衛星放送, 次世代携带電話 などの移動体通信用のアンテナ, ITS, ETC P AHS など 高周波を使用する通信関係に使用されている.

(6) 絶縁断熱材

PTFE 含浸繊維織布を多層に積層後板状に成形したもの で，炉の断熱材や絶縁材などに使用されている.

\section{6. 建築用膜材料}

建築用膜材料とは，図 4 のように織布の両面，及び内部 に樹脂をコーティング或いは含浸させた柔軟な繊維補強複 合材料である. 主に繊維は膜材料の力学的特性を, コーティ ング材は防水性, 耐久性などの物理的特性を高めている. 現在, 建築用として一般に使用されている膜材料 (テント) としては，材料構成から大きく 3 種類に分けられる. ガラ ス繊維織布に PTFEを被覆したもの, ガラス繊維織布に ポリ塩化ビニル樹脂（PVC）を被覆したもの, ポリエス テル繊維織布にPVC を被覆したものであり, 日本国内で はそれぞれ $\mathrm{A}$ 種, $\mathrm{B}$ 種, $\mathrm{C}$ 種膜材料と呼ばれている.

また，これらの膜材料を使用した膜構造物は，それぞれ の構造方式からサスペンション膜構造, 骨組み膜構造, 空 気膜構造と分けられる。

(1) 膜構造の歴史 ${ }^{1)}$

膜構造としては, 最も古いものはイタリアのポンペイ円 形劇場で紀元 59 年に建設されたサスペンション構造の膜 建築物といわれている。般的には, 古くから世界の遊牧 民が使用しているテント式住居（モンゴルのゲルなど）が 有名かと思う。

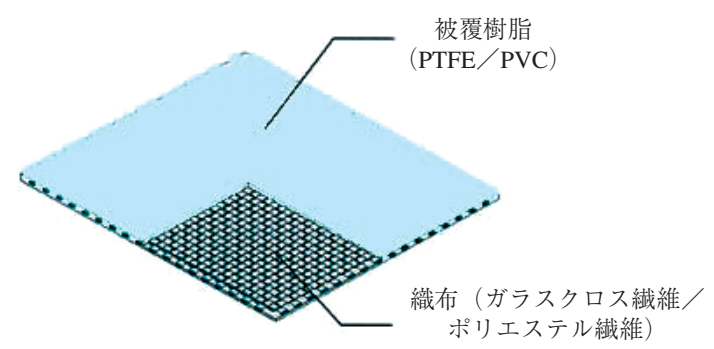

図 4 膜材料構成
しかしそれらは，膜面に張力を導入して構造の安定性を 高めると言う考え方はなく, 膜面を支える柱の配置や梁を 工夫する事で，その上に膜を設置するだけのものであった.

これが 1950 年頃になると, 当時西ドイッの Frei Paul Otto により鞍形曲面に初期張力を導入した膜構造が誕生 した。この新しい考え方をきっかけに膜構造は, 1967 年 カナダ・モントリオール万博の西ドイツ館, 1973 年ラバー ン大学体育館と巨大なサスペンション膜構造物と変革して いった.

一方空気膜構造は，1783 年の Montgolfier 兄弟による熱 気球，そして飛行船と変貌し，20世紀前半，イギリスの Frederic W. Lanchester の手により地上の建築物として世 に誕生することとなった。この空気膜構造は，1946 年ア メリカでレーダードーム（レドーム）として建設されて以 来，1972 年アメリカのミリガン大学に PTFEを含浸した ガラス繊維織布による恒久的な建築物が完成されるに至る.

(2) 膜材料開発の歴史

当社は，アメリカに遅れながらも 1970 年代に恒久建築 物用の膜材料としての開発をスタートした。それまで培っ てきた繊維織布にPTFE を含浸する技術を発展させ，高 強度, 高耐久性膜材料として 1980 年代には，製造技術と して完成の域に達していた。

日本では，東京ドームの建設を皮切りに，各地で体育施 設を中心に様々な膜構造建築物が建設されることとなり， 現在, 当社製品での国内施工実績は 1,000 件以上にのぼる. (3) 膜材料の特性

先ほど膜材料としては, 材料構成によって 3 種類の膜材 料があることを説明した．当社で製造している膜材料はそ の中の A 種でガラス繊維織布に PTFEを被覆した恒久建 築物用膜材料である。

ガラス繊維には, 現在工業的に生産されている中では最 も細い $3 \mu \mathrm{m}$ フィラメントを収束させた B ヤーンと呼ばれ るガラス繊維を使用している. フィラメント径が小さいと 言うことは，同じガラス繊維でも高強度でありながら柔軟 性を持ったガラス繊維である。

B ヤーンを使用した $\mathrm{A}$ 種は，耐屈曲性に優れ，屋外の 風, 雨の外力に対しての耐久性を備えている.

(1)軽量

従来工法のスチール屋根と比較すると，屋根荷重は約 1 /30である.

(2)自由な設計

膜構造は，一般に内部支持要素を用いずに大空間を膜材 料で覆う事が可能なので，自由な設計，多様な空間利用が 可能である.

(3)不燃性

PTFE 膜材料は，不燃性の高いガラス繊維と PTFE の 複合材料であり，国土交通省の建築材料として不燃認定を 受けている.

(4)強勒性

ガラス繊維は，B ヤーンを使用しており，膜構造を構成 するに当たり充分な強度と安全性を確保している.

(5)透光性

PTFE 膜材料は, 半透明で, 構造物内に自然な拡散光を 取り入れることができ，ソフトな空間演出が可能となる. 
(6) 熱的特性

PTFE 膜材料の白色が太陽エネルギーの大部分を反射す るため, 構造物内への熱の侵入を抑えることが出来る。さ らに内膜 (吸音膜) を使用した二重膜構造にすることで, 冷暖房の断熱効果が向上し, 省エネに適した材料と言える. (7)耐候性

耐薬品性, 耐候性に優れるPTFEで完全に被覆されて いるため, 紫外線や大気污染に対して不活性で, 屋根とし ての機能と安全性を長期間にわたり維持できる.

(8)セルフクリーニング性

表面の PTFE は非粘着性に優れており，膜材料の表面 に堆積したホコリや大気污染物質等は, 雨が降るたびに洗 い流される。

(9)吸音性

内装用吸音膜は，適度な柔軟性と通気性を有しているた め, 優れた吸音効果を持っている. 二重膜として使用する ことで, 構造物内の音響効果を高めることが出来る.

（4）最近の実績

当社では, 昨年話題になった北京オリンピックのメイン スタジアム向けとして吸音膜の開発を行なった.メインス タジアムの屋根の構造は, 屋外屋根がシルバーのドットが 印刷された，透明の ETFEフィルムで覆われたものであ る. 音響 - 遮光 - 意匠面から内装膜として調光及び吸音膜
が必要となり，当社も開発に着手した。

当社では, 他社の提案に納得しない設計陣に対し, 要求 性能を全て満足するような吸音膜の開発という経営者判断 により，対極の性能を満たす製品開発に着手することと なった。

これまで培ってきた含浸技術を存分に応用し，ガラス繊 維織布の新規設計, PTFE 原料の濃度, 加熱乾燥条件の検 討によって, 全ての要求特性を満足する吸音膜材料を開発 することが出来た.

（5）今後の展開

当社ではパネルモジュール等の一般消費財用途のほか, 内装用途への新たな展開に着手した. 今まで限られたファ ブリケーターに限定されていた製品をもっと身近に広げた いと考えている.

そのほかにも, 地震等の災害時に避難所になるような公 共施設に対し, 落下や崩落の心配が無く, 安全面を重視し た天井材としての提案も継続して実施している.

認知度，施工事例は未だ微々たる物であるが，当社製品 の多様さを生かし，今後の各業界での採用に期待したい.

\section{参 考 文 献}

1 ) 膜構造建築物開発委員会 : 膜構造 - その現状と展望 1.1.1，10，(社)日本膜構造協会，（1986）

\section{賛助会員ならびに会員の皆様へ}

\section{「知りたい，見たい，訪ねたい一成形加工の元気な仲間一」の 訪問取材を希望される会社を募集中}

「成形加工」誌には，「知りたい，見たい，訪ねたい一成形加工の元気な仲間一」を掲載しています．本企画は， プラスチック成形加工に携わり，日本のものづくり産業の基盤を支えている活気ある企業を，本誌編集委員自ら が訪問取材して，会社概要および自慢の製品・技術を広く会員に紹介することを目的としたもので，詳細は以下 のとおりです.

1. 主として賛助会員あるいは正会員の所属する会社を，本誌編集委員が訪問し，新製品・新技術等を，実際 の製品を見て，あるいは現場見学を交えて取材し，記事としてまとめ上げる．会員による原稿執筆は一切 不要.

2. 取材は, 2 時間程度.

3. 原稿は, 図表を含めて刷り上がり 2〜3ページとする.

4. 掲載料は無料.

この「知りたい, 見たい, 訪ねたい一成形加工の元気な仲間一」の訪問取材を是非ご検討下さい.

本企画は，年間 4〜 5 件を掲載する予定です。記事のスタイル，内容等につきましてはすでに掲載されている 幾つかの記事をご参照下さい.

「成形加工」編集委員長 大嶋正裕 